\title{
Editorial
}

\section{Donald Trump as global constitutional breaching experiment}

J O N A THA N H A VERCROFT, A N T E W I E N E R, M A T T I A K U M M and JEFFREY L D U N O F F

The publication of this issue of Global Constitutionalism comes a little over a year since Donald Trump was sworn in as President of the United States. Over the ensuing 13 months it has become commonplace to observe that the actions of this President are 'not normal'. Examples of his abnormal behaviour are numerous, but for a quick refresher consider the following (very incomplete) list. Calling the director of the National Parks Service to find photos of the inauguration to disprove media claims that President Obama's inauguration had a larger audience. ${ }^{1}$ Launching an investigation into voter fraud over the election he won, without any actual evidence of voter fraud. ${ }^{2}$ Hanging up on the Australian Prime Minister because he did not like a pre-existing refugee agreement between the US and Australia. ${ }^{3}$ Pressuring the director of the FBI to stop investigating Michael Flynn for his undisclosed dealings with Russia and Turkey. Banning major media outlets from White House press briefings because he did not like the coverage he received from these organisations. ${ }^{4}$ Accusing President Obama of wire tapping Trump's

1 'Donald Trump Personally Called National Park Service Director about Those Inauguration Photos' The Independent (27 January 2017) <http://www.independent.co.uk/news/world/ americas/donald-trump-national-park-service-michael-reynolds-inauguration-crowd-sizephotos-proof-a 7548601.html>.

2 A Parker, 'Trump Says Pence Will Head Investigation into Voting Irregularities, despite No Evidence of Fraud' Washington Post (5 February 2017) Post Politics, <https://www. washingtonpost.com/news/post-politics/wp/2017/02/05/trump-says-pence-will-headinvestigation-into-voting-irregularities-despite-lack-of-evidence-of-fraud/>.

3 'Donald Trump and Malcolm Turnbull's Phone Call: The Full Transcript' ABC News (3 August 2017) <http://www.abc.net.au/news/2017-08-04/donald-trump-malcolm-turnbullrefugee-phone-call-transcript/8773422>.

${ }^{4} \mathrm{~S}$ Siddiqui, 'Trump Press Ban: BBC, CNN and Guardian Denied Access to Briefing' The Guardian (25 February 2017) US news, <http://www.theguardian.com/us-news/2017/feb/24/ media-blocked-white-house-briefing-sean-spicer>. 
offices in Trump Tower. ${ }^{5}$ Attacking courts and judges who have ruled against him on the 'Muslim travel ban'. ${ }^{6}$ Leaking classified intelligence from a US ally (widely reported in the press to be Israel) to the Ambassador of Russia. ${ }^{7}$ Firing the director of the FBI because of an ongoing investigation. ${ }^{8}$ Withdrawing the United States from the Paris International Climate Agreement. ${ }^{9}$ Criticising the Muslim mayor of London (via Twitter) for his response to a terrorist attack on London Bridge. ${ }^{10}$ Delivering a speech at the Boy Scouts Jamboree full of angry political rhetoric. ${ }^{11}$ Refusing to condemn a Neo-Nazi rally that resulted in three deaths and thirty-eight injuries. ${ }^{12}$ Threatening North Korea with 'total destruction' during his inaugural speech to the UN. ${ }^{13}$ Ending the highly popular DACA (Deferred Action for Childhood Arrivals) programme. ${ }^{14}$ Endorsing a candidate for Senate who was facing numerous accusations of making sexual advances

5 DJ Trump, 'Terrible! Just Found out That Obama Had My "Wires Tapped" in Trump Tower Just before the Victory. Nothing Found. This Is McCarthyism!' Tweet, @realDonaldTrump (blog), (3 March 2017) <https://twitter.com/realDonaldTrump/status/837989835818287106? ref_ src $=$ twsrc $\% 5$ Etfw $>$.

6 J Fabian, 'Trump Attacks Judges Weighing Travel Ban' The Hill (8 February 2017) <http:// thehill.com/homenews/administration/318451-trump-attacks-judges-weighing-travel-ban>.

7 G Miller and G Jaffe, 'Trump Revealed Highly Classified Information to Russian Foreign Minister and Ambassador' Washington Post (15 May 2017) National Security, <https://www. washingtonpost.com/world/national-security/trump-revealed-highly-classified-information-torussian-foreign-minister-and-ambassador/2017/05/15/530c172a-3960-11e7-9e48c4f199710b69_story.html>.

8 M Haberman et al., “"Enough Was Enough”: How Festering Anger at Comey Ended in His Firing' New York Times (10 May 2017) Politics, <http://www.nytimes.com/2017/05/10/ us/politics/how-trump-decided-to-fire-james-comey.html>.

9 B Chakraborty, 'Paris Agreement on Climate Change: US Withdraws as Trump Calls It “Unfair"” Fox News (1 June 2017) Politics <http://www.foxnews.com/politics/2017/06/01/ trump-u-s-to-withdraw-from-paris-climate-pact-calls-it-unfair-for-america.html>.

10 DJ Trump, 'Pathetic Excuse by London Mayor Sadiq Khan Who Had to Think Fast on His "No Reason to Be Alarmed" Statement. MSM Is Working Hard to Sell It!' Tweet, @realdonaldtrump (blog) (6 June 2017) <https://twitter.com/realdonaldtrump/status/ 871725780535062528 ?lang=en>.

11 'Trump Boy Scout Jamboree Speech Angers Parents' BBC News (25 July 2017) US \& Canada, <http://www.bbc.co.uk/news/world-us-canada-40715185>.

12 M Oppenheim, 'Neo-Nazis and White Supremacists Applaud Donald Trump's Response to Deadly Violence in Virginia' The Independent (13 August 2017) <http://www.independent. co.uk/news/world/americas/neo-nazis-white-supremacists-celebrate-trump-response-virginiacharlottesville-a7890786.html>.

13 J Borger at the United Nations, 'A Blunt, Fearful Rant: Trump's UN Speech Left Presidential Norms in the Dust' The Guardian (19 September 2017) US news, <http://www. theguardian.com/us-news/2017/sep/19/donald-trump-un-speech-analysis-north-korea .

${ }_{14}$ MD Shear and J Hirschfeld Davis, 'Trump Moves to End DACA and Calls on Congress to Act' New York Times (5 September 2017) Politics, <https:/www.nytimes.com/2017/09/05/ us/politics/trump-daca-dreamers-immigration.html>. 
on young teenage girls. ${ }^{15}$ One could certainly provide far more examples. A common thread in the public and media response to all of these different episodes is that Trump's behaviour defies public expectations of what is normal, standard and expected. As Martin Wolf, writing in the Financial Times, puts it, Trump's actions and statements 'violates the behaviour and attitudes the world expects of a US president' on a regular basis. ${ }^{16}$ Translated into the language of social science, the Trump Presidency's basic pattern has been one of violating norms; the social expectations that guide appropriate behaviour for actors in a given context.

One concern frequently expressed by critics of President Trump is that the constant breaking of norms could result in Trump and his political movement undoing the foundations of democracy through disruptive action. ${ }^{17}$ Indeed, Steve Bannon, the President's former chief advisor, openly embraced disruption as both modus operandi and political goal. This strategy and goal implicitly recognises what scholars of political institutions have long argued: because written rules cannot govern all aspects of human behaviour, many institutions require that participants in their processes abide by implicit norms in order to sustain their basic practices. The same accounts for the implementation of legal regulations that depend on social recognition within a wider socio-cultural context for interpretation. ${ }^{18}$ There are, for instance, no written laws that dictate that the President must give a daily briefing to the press, or that all major media outlets be given White House press credentials. But when the Trump White House began to threaten to pull credentials for reporters whose coverage they did not like, this violated a basic democratic norm that the press have access to the office of the President and be able to ask challenging and probing questions. Without a press that is able to confront the government

15 M Vazquez, 'Trump Calls Roy Moore to Offer His Endorsement' CNN (4 December 2017) <http://www.cnn.com/2017/12/04/politics/trump-moore-endorsement-twitter/index.html>.

${ }^{16} \mathrm{M}$ Wolf, 'The New World Disorder and the Fracturing of the West' Financial Times (2 January 2018).

17 'Will Donald Trump Destroy the Presidency?' The Atlantic (7 December 2017) $<$ https://www.theatlantic.com/magazine/archive/2017/10/will-donald-trump-destroy-thepresidency/537921/>; E Bazelon, 'How Do We Contend with Trump's Defiance of "Norms"?' (11 July 2017) <https://www.nytimes.com/2017/07/11/magazine/how-do-we-contend-withtrumps-defiance-of-norms.html>; A Gopnik, 'Norms and Cliffs in Trump's America' The New Yorker (3 August 2017) <https://www.newyorker.com/news/daily-comment/norms-and-cliffsin-trumps-america>; H Farrell and M Finnemore, 'Trump's No Hypocrite' Foreign Affairs (30 May 2017) <www.foreignaffairs.com/articles/2017-05-30/trump-s-no-hypocrite>.

18 M Finnemore and SJ Toope, 'Alternatives to "Legalization": Richer Views of Law and Politics' 55(3) International Organization (2001) $743<$ https://doi.org/10.1162/ 00208180152507614>. A Dahl, Polyarchy: Participation and Opposition (Yale University Press, New Haven, CT, 1971). 
on a daily basis, modern mass democracy would simply not function. The concern expressed by many commentators critical of Trump's norm-breaking habit is that as he has systematically violated so many basic norms on so many fronts, this behaviour may lead to an unravelling of the very institutions necessary to sustain democracy. For global constitutionalists, this raises the question whether this kind of disruptive action triggers a 'critical juncture' that is constitutive for long-lasting effects on what is considered as acceptable behaviour in a democracy. ${ }^{19}$ As it becomes taken for granted, in the long term Trump's disruptive action might constitute a change in the ethics of democratic norms.

In this editorial, we argue that even though from the global constitutionalist perspective Trumpism represents an attack on the three foundational features of the global constitution - democracy, human rights, and the rule of law, the ultimate effects of that attack are yet to be determined. It is possible that, in some instances, the effect of Trump's actions - and the response to Trump's behaviour - may be to more deeply anchor and stabilise constitutionalist commitments.

That Trump's behaviour constitutes an attack on constitutionalist norms is straightforward enough. Consider his behaviour with respect to norms surrounding democratic practice. While the Mueller investigation is ongoing, and no definitive conclusions have been reached, the central allegation that launched the investigation is that the Trump campaign colluded with agents of the Russian government to hack the email accounts of the DNC and the Clinton campaign, and to launch a social media campaign using information gained from those hacks to influence the behaviour of voters. Whether or not this campaign happened as alleged, or had the impact on the election that Trump critics occasionally claim, the larger ethical issue is: did this possible collaboration with a foreign power violate basic norms about how to conduct open elections? Does collaborating with a hostile foreign power to gain information to embarrass one's opponent and to distort the information that voters receive about a candidate violate basic norms about what type of information voters receive during an election?

Many democracies place strict limits on how much media exposure campaigns can have, and put in place rules to regulate how campaigns can

19 See G Capoccia and RD Kelemen, 'The Study of Critical Junctures: Theory, Narrative, and Counterfactuals in Historical Institutionalism' 59(3) World Politics 341; A Wiener, 'Trump and the End of Taken-for-Grantedness: When Exception Becomes the Rule' (13 December 2016) Duck of Minerva Blog <http://duckofminerva.com/2016/12/wptpn-trump-and-the-end-of-takenfor-grantedness-when-the-exception-becomes-the-rule.html>; we also touched on this theme in last year's editorial: M Kumm et al., 'Editorial: The End of "the West" and the Future of Global Constitutionalism' (2017) 6(1) Global Constitutionalism 1 <https://doi.org/10.1017/ S2045381717000077>. 
advertise, precisely because of fears about how propaganda, falsehoods, and unbalanced media coverage can unfairly influence the election. Yet Trump's and his surrogates' response to the allegations has been twofold: first to deny the validity of the story, and when caught with incontrovertible evidence of collaboration, to dismiss the findings as irrelevant because nothing was illegal. The second rhetorical manoeuvre is more damaging to democracy in the long term, because if the public does not treat this sort of behaviour as unacceptable, it may become accepted practice to disseminate falsehoods on social media with the aim of distorting the outcome of elections, and it could become increasingly acceptable for foreign powers to offer assistance to a candidate in conducting propaganda campaigns in exchange for political favours should the candidate win. While the actual act of voting may not end, the norm that voters be given as much factual information on the issues on which they are voting may be eroded, leading to a kind of authoritarian democracy where the powerful few use advanced algorithms and sophisticated social media campaigns to distort voter behaviour. As is the case in many authoritarian regimes, the government may continue to hold elections, but by ensuring that they are neither free nor fair, the few ensure the outcome of the election before it is even held. Undermining norms about how campaigns fight an election threatens not only the integrity of a specific election, but to undermine democracy itself.

In the case of human rights, Trump has been dismissive of the torture prohibition, ${ }^{20}$ and his tendency to subvert due process by tweeting against criminal suspects, ${ }^{21}$ as well as his public encouragement of police brutality ${ }^{22}$ are all cases of him challenging long-settled norms around human rights. Attempts by the Trump administration to reopen CIA black sites and permit torture of CIA detainees is an attempt to return US government practices to the darkest days of the Bush administration. ${ }^{23}$ Yet the crucial difference between Trump's approach and Bush's is that the Bush administration went to great lengths to conceal the scope of its torture

20 A Serwer, 'Can Trump Bring Back Torture?’ The Atlantic (26 January 2017) <https://www. theatlantic.com/politics/archive/2017/01/trump-torture/514463/>.

21 'Trump May Have Just Destroyed the Legal Case against the New York Terror Suspect'> The Independent (2 November 2017) <http://www.independent.co.uk/news/world/americas/ us-politics/new-york-attack-donald-trump-tweet-sayfullo-saipov-legal-case-destroy-damageterror-suspect-death-a8032746.html>.

22 'Donald Trump Seemingly Endorses Police Brutality' The Independent (28 July 2017) $<$ http://www.independent.co.uk/news/world/americas/us-politics/donald-trump-long-islandbrutality-police-suffolk-a7866071.html>.

23 'Trump May Reinstate Secret CIA “Black Site” Prisons: U.S. Officials' Reuters (25 January 2017) <https://www.reuters.com/article/us-usa-trump-prisons/trump-administrationcould-reinstate-secret-overseas-cia-prisons-washpost-idUSKBN15922L >. 
programme by shifting the focus from the moral reach of the torture prohibition norm towards the effect of interrogation technologies. ${ }^{24}$ (One of the main claims of the constructivist literature in international relations is that moments of hypocrisy by government officials - i.e. moments when governments attempt to conceal behaviour that they know is wrong - is a sign of a norm's 'robustness' ${ }^{25}$ From this perspective, the Bush administration's attempt to conceal its torture programme was a tacit admission that it knew the practice was wrong, or at the very least violated international norms. Trump conversely attacks the very norm itself by calling for practices such as extrajudicial killings, the suspension of due process in cases of terrorism, and torture of suspected terrorist to be normalised. In other words, Trump is not simply seeking to violate the norm for expediency sake (as the Bush administration was); rather Trump is trying to end the norm itself.

With respect to the rule of law, President Trump has repeatedly expressed his frustration that he is not, as President, permitted to directly interfere in the US judicial system. Trump has pressured the FBI to pursue cases against his political adversaries such as Hillary Clinton. He has made public complaints that he is not able to direct FBI investigations. He publicly criticised the conviction of Sergeant Bergdhal and has called on Twitter for New York terrorist suspect Sayfullo Saipov to get the death penalty. ${ }^{26}$ Trump's public frustration at not being able to direct the American judicial system to enact his particular whims, strikes at the heart of the principle of the rule of law. The principle behind the rule of law is that the law, rather than the whims of individual rulers, should govern the state, and that all should be equally subjected to the law. Trump's actions in the first year in office show that he is at the very least open to an authoritarian form of government, where the decisions of leaders govern a society.

${ }^{24}$ VC Keating, 'Contesting the International Illegitimacy of Torture: The Bush Administration's Failure to Legitimate Its Preferences within International Society' (February 2014) 16(1) The British Journal of Politics and International Relations 1 <https://doi. org/10.1111/1467-856X.12024>; B Steele, 'Broadening the Contestation of Norms in International Relations' (January 2017) 49(1) Polity 132 <https://doi.org/10.1086/689981>; ME Newell, 'Interstitial Rules and the Contested Application of Human Rights Law and the Laws of War in Counterterrorism' (2016) 5(2) Global Constitutionalism 207 <https://doi.org/ 10.1017/S2045381716000071>.

25 A Schmidt and S Kathryn, 'Explaining the Impact of US Contestation of the Torture Ban' (2017) unpublished manuscript.

26 'New York Truck Attack: Trump Urges Death Penalty for Sayfullo Saipov' BBC News (3 November 2017) US \& Canada, <http://www.bbc.co.uk/news/world-us-canada-41848151>; D Diaz CNN, 'Trump on Bergdahl Decision: "Complete and Total Disgrace"' CNN (3 November 2017) <http://www.cnn.com/2017/11/03/politics/donald-trump-bowe-bergdahl-twitter/index. html>. 
When we consider the pattern of Trump's behaviour in aggregate his actions as President present a disturbing pattern of repeatedly challenging the settled norms of liberal democracy. He aims to challenge some of the basic rules of fair elections to ensure he has a better chance of winning. He finds norms about human rights and the rule of law inconvenient obstacles to him being able to use the instruments of state to punish his political enemies and those (such as Latino and Muslim immigrants) to whom he has repeatedly expressed a strong aversion. Trumpism represents a decisive threat to democracy, human rights, the rule of law and individual freedoms as the fundamental norms of global constitutionalism. ${ }^{27}$

Yet, as we argued in last year's editorial, ${ }^{28}$ despite recent geopolitical events, we need not consider the global constitutional order dead, let alone severely debilitated. ${ }^{29}$ Considered from a different perspective, Trump's constant attacks on basic norms of liberal democracy may not be undermining the system so much as re-energising it. One way of thinking of Trump's behaviour is as a global 'breaching experiment'. The sociologist Harold Garfinkel argued, for example, that our conduct in everyday affairs rested on shared background understandings that constituted the invisible structures of everyday life. ${ }^{30}$ Most participants in any social institution are unable to articulate the social rules, norms, and shared understandings that guide their behaviour. Garfinkel proposed a simple way to make these implicit rules explicit was for the ethnologist to engage in breaching experiments. In one instance, Garfinkel asked his students to go home and act as if they were a boarder in the family home for an hour. The students would behave far more politely than normal, and be inquisitive about what the normal customs of the household were. What the students discovered is that this behaviour in almost every instance elicited a negative response from the family, and the students also discovered that the family setting was often far less friendly and cordial than they imagined (many students, in fact, protested that the family structure revealed through the

27 AF Lang and A Wiener (eds), Handbook on Global Constitutionalism (Edward Elgar Publishing, Cheltenham, 2017).

28 M Kumm et al., 'Editorial: The End of 'the West' and the Future of Global Constitutionalism' (2017) 6(1) Global Constitutionalism 1 <https://doi.org/10.1017/S2045381717000077>.

29 While not discussing Trumpism, other scholars have noted how moves that might seem to undermine global constitutionalism, such as independence movements, might actually end up reinforcing cosmopolitan tendencies. KM Fierke, 'Introduction: Independence, Global Entanglement and the Co-Production of Sovereignty' (2017) 6(2) Global Constitutionalism 167 <https://doi.org/10.1017/S2045381717000089>; S Benhabib, 'The New Sovereigntism and Transnational Law: Legal Utopianism, Democratic Scepticism and Statist Realism' (2016) 5(1) Global Constitutionalism 109 <https://doi.org/10.1017/S2045381716000010>.

${ }^{30} \mathrm{H}$ Garfinkel, Studies in Ethnomethodology (2nd rev edn, Polity Press, Cambridge, 1984) ch 2. 
experiment was not their 'real family'). Garfinkel's point was that by acting in a manner that contradicted the implicit rules of a social encounter, one could demonstrate that those shared, invisible norms, actually existed. Norm violation demonstrated the existence and validity of a norm, and so long as those not participating in the breaching experiment reacted with hostility to norm violation the experimenter could assume that these hidden rules of shared understanding were shaping social conduct. ${ }^{31}$

While Garfinkel called for intentional and inauthentic violations of implicit norms, we could view Trump's behaviour as a kind of natural breaching experiment. Trump is not deliberately trying to breach norms for the purposes of social scientific discovery. His precise motives, and the question of whether his repeated pattern of norm violation is part of a brilliant political strategy or the result of an individual who is normatively incompetent, are not questions that need detain us here. From the perspective of the study of global constitutionalism, however, this natural breaching experiment is doubly useful. First for those who are sceptical about both the existence and the influence of norms in global politics, Trump's repeatedly breaching of these norms, and the hostile reactions these breachings elicit from the global public, are at the very least evidence that most actors in the global polity abide by a widely held set of implicit background assumptions. Second by making the implicit, explicit, Trump has made these norms a 'site of contestation': each time and place where a fundamental norm is contested, a novel site is constituted. According to recent international relations theory, such on-site contestations are conceptualised as a condition for enhancing global justice, as long as affected stakeholders are granted access to them. ${ }^{32}$

Here is the catch - and the ultimate long-term effect - of Trumpism, however: while using social media and inviting individual stakeholders around the globe to comment, his disruptive politics relies on the President's ultimate control over who says what when and how. The publicly stated objective of right-wing populists such as Trump, Farage and Bannon is

31 J Tully, Public Philosophy in a New Key: Vol 1, Democracy and Civic Freedom (1st edn, Cambridge University Press, Cambridge, 2009) 125; M Hofius, 'Community at the Border or the Boundaries of Community? The Case of EU Field Diplomats' (2016) 42(5) Review of International Studies 939 <https://doi.org/10.1017/s0260210516000085>.

32 A Wiener, Contestation and Constitution of Norms in Global Governance (Cambridge University Press, Cambridge, 2018); A Wiener, 'Agency of the Governed in Global International Relations: Access to Norm Validation’ (28 July 2017) Third World Thematics: A TWQ Journal 1 <https://doi.org/10.1080/23802014.2017.1359064>. J Havercroft and R Duvall, 'Challenges of an Agonistic Constructivism for International Relations' (2017) 49(1) Polity 156 <https://doi.org/10.1086/689978>. 
to challenge these norms with the goal of ending them. ${ }^{33}$ Yet each norm violation has also provoked a significant global backlash, mobilising advocates to protect (and in some cases further develop and entrench) basic norms that are now under attack. Let's consider three examples to examine this dynamic: Trump's public boastings of sexual harassment and the rise of the \#MeToo movement; Trump's withdrawal from the Paris Climate Accord and a counter mobilisation to promote greenhouse emission reductions; and Trump's attempts to roll back legal immigration leading to a counter mobilisation in support of migrant rights.

One of the central critiques of Donald Trump during the Presidential campaign was his long and well-documented sexist behaviour towards women. This attack culminated in the release of a tape from Access Hollywood where Donald Trump boasted about sexually assaulting women. ${ }^{34}$ This in turn led to numerous allegations by women claiming that they had been sexually assaulted by Trump in precisely the ways that he described in the video. ${ }^{35}$ While Trump and his campaigned dismissed the tape as 'locker room talk' 36 and the allegations as 'fake news' 37 the issue has not gone away. As recently as December the accusations against Trump have been front-page news in the US. ${ }^{38}$ While the cynical response may be that despite all the mounting evidence against Trump of his history of sexual harassment and sexual assault none of it seems to matter, this ignores several factors. First the lowest point in Trump's poll numbers during the Presidential campaign was in the weeks immediately following

33 D Weigel, 'Steve Bannon's Rise Points to Aggressive, Anti-'Globalist' Trump Media Strategy' Washington Post (14 November 2016) Post Politics, <https://www.washingtonpost. com/news/post-politics/wp/2016/11/14/steve-bannons-rise-points-to-aggressive-anti-globalisttrump-media-strategy/>.

${ }^{34}$ DA Fahrenthold, 'Trump Recorded Having Extremely Lewd Conversation about Women in 2005' Washington Post (8 October 2016) Politics, <https://www.washingtonpost.com/ politics/trump-recorded-having-extremely-lewd-conversation-about-women-in-2005/2016/10/ 07/3b9ce776-8cb4-11e6-bf8a-3d26847eeed4_story.html>.

35 A Parker, M Berman, and FS Sellers, 'Three Women Reassert Allegations of Sexual Harassment against President Trump' Washington Post (12 December 2017) Politics, <https:// www.washingtonpost.com/politics/three-women-reassert-allegations-of-sexual-harassmentagainst-president-trump/2017/12/11/9aa208a2-de96-11e7-bbd0-9dfb2e37492a_story.html>.

36 CBS/AP, “I Never Said I'm a Perfect Person” Trump Says about Lewd Comments' (7 October 2016) <https://www.cbsnews.com/news/donald-trump-defends-lewd-2005conversation-about-women-as-locker-room-banter/>.

37 A Parker, "Trump Seeks to Dismiss Sexual Harassment Allegations as "Fake News", Washington Post (12 December 2017) Post Politics, <https://www.washingtonpost.com/ news/post-politics/wp/2017/12/12/trump-seeks-to-dismiss-sexual-harassment-allegations-asfake-news/>.

38 Parker Berman and Sellers (n 35). 
the release of the Access Hollywood tape. ${ }^{39}$ To call the 2016 US Presidential Campaign a messy affair would be an understatement. While the tape was not the decisive factor in how the campaign ended, it did have a negative impact on Trump's image. And that negative image continues into his presidency, as Trump has consistently been the President with the lowest approval numbers for a first-year President in the history of polling. ${ }^{40}$

Yet to only focus on how the controversy affected candidate Trump is to miss its larger significance. The election of Donald Trump has galvanised the feminist movement in a way it hasn't been in decades. The Trump's inauguration was met by the Women's March, a day of global protests attacking the Presidency of Donald Trump and demanding greater recognition of women's rights. The march in Washington, DC was the largest demonstration since the anti-Vietnam War protests of the 1960s and 1970s. ${ }^{41}$ This was followed by a series of exposés of workplace sexual harassment and assault leading to the public shaming and dismissal of celebrities such as Harvey Weinstein, Louis C.K., and Matt Lauer. Whereas in the past celebrities facing serious allegations of sexual assault, such as Woody Allen and Roman Polanski, have been able to dismiss these types of allegations as untrue and continue on with successful careers, in the post-Trump era allegations of sexual assault amongst the famous and powerful are career-ending. Furthermore, the focus on high-profile cases in the mass media has led in turn to a social media campaign called \#MeToo where women have used platforms such as Twitter and Facebook to call out everyday sexual harassment in the workplace. From a breaching experiment point of view we could see Trump's violating the implicit norms against sexual assault as provoking a backlash that is confronting the problem more forcefully and systematically. Prior to Trump a norm had developed against sexual harassment, yet actual incidents of sexual harassment - especially by powerful men - were not treated seriously. We can see that the norm existed as the response to an accusation was to deny the charge - why deny doing something if one did not think the action one was accused of was wrong after all? As Walzer, quoting La

39 C Kahn, 'Trump Trails Clinton by 8 Points after Tape Scandal, Debate: Reuters/Ipsos Poll' Reuters (11 October 2016) <https://www.reuters.com/article/us-usa-election-poll/trumptrails-clinton-by-8-points-after-tape-scandal-debate-reuters-ipsos-poll-idUSKCN12B2PV>.

$40 \mathrm{~J}$ Calfas, 'President Trump's Approval Rating Is Lower Than Any Modern President' Time (5 November 2017) <http://time.com/5010653/donald-trump-approval-ratings-low-poll/>.

41 E Chenoweth and J Pressman, 'This Is What We Learned by Counting the Women's Marches' Washington Post (17 February 2017) Monkey Cage: Analysis interpretation of the news based on evidence, including data, as well as anticipating how events might unfold based on past events, <https://www.washingtonpost.com/news/monkey-cage/wp/2017/02/07/this-iswhat-we-learned-by-counting-the-womens-marches/>. 
Rochefoucauld observed, 'hypocrisy is a tribute vice pays to virtue'. ${ }^{42}$ If one acts one way, but then denies the behaviour, one is implicitly saying that one recognises the action as wrong. ${ }^{43}$ In the case of Trump he is dismissive of accusations that his behaviour is wrong. He is not a hypocrite, because he does not deny doing the activity. In breaching the norm, he is contesting it, with the hope of rolling it back. Yet various feminist movements have pushed back against both Trump's behaviour in particular, and the manifestations of sexual harassment and assault in general. By breaching the norm, Trump generated a counter-movement to defend and extend the norm.

Similarly Donald Trump's decision to withdraw from the Paris Climate Agreement prompted a global backlash. In this instance the agreement itself was new only being signed in 2016. President Trump gave notice of the United State's intention to withdraw from the treaty in August 2017. Because of the structure of the agreement, the US cannot actually withdraw until November $2020 .{ }^{44}$ So there is the possibility that should a more environmentally friendly candidate win the next US Presidential election the withdrawal could be undone. More significant, however, is the fact that every other signatory to the agreement remains party to it, making the US an isolated outlier when it comes to the agreement. Furthermore within the US state-level governments, major corporations and mayors of major cities have all signed separate agreements to implement key aspects of the Paris Climate Agreement despite the US withdrawal. ${ }^{45}$ So while the headline may be that President Trump is threatening the planet by leaving the Paris Agreement, in practice the global commitment to the norm that carbon emissions pose an unacceptable threat to life on the planet and must be reduced is so robust that even major petrochemical producers protest when Trump withdraws from the agreement.

One major policy area where Donald Trump has had the most success so far in implementing campaign promises is in the area of immigration. While the courts initially blocked his so-called 'Muslim ban', the Supreme

42 Le Duc de La Rochefoucauld, Maxims, trans J Heard (International Pocket Library, Boston, MA, 1982) maxim 223.

43 For a development of La Rochefoucauld's maxim as it applies to the laws of war see M Walzer, Just and Unjust Wars: A Moral Argument with Historical Illustrations (Basic Books, New York, NY, 2006) 19-20.

44 'U.S. Submits Formal Notice of Withdrawal from Paris Climate Pact' Reuters (4 August 2017 ) <https://www.reuters.com/article/us-un-climate-usa-paris/u-s-submits-formal-notice-ofwithdrawal-from-paris-climate-pact-idUSKBN1AK2FM>.

45 'US Cities and Companies Declare "We Are Still in" Paris Agreement despite Trump' The Independent (10 November 2017) <http://www.independent.co.uk/news/paris-agreementtrump-us-cities-still-in-defiance-coalition-a8047086.html>. 
Court has since permitted the administration to implement significant portions of the revised travel ban. The Trump Administration has ended Deferred Action for Childhood Arrivals (DACA), but given Congress six months to develop an alternative. ${ }^{46}$ The administration has also greatly restricted the number of refugees it admits, and escalated the rate at which Immigration Control and Enforcement (ICE) is ordering the removal undocumented migrants. ${ }^{47}$ It is interesting to note that Trump has been most successful in the domain where he uses the rhetoric of 'illegality' that is the argument that those he pushes to deport entered the US without legal documentation, or his claim that banning entrants from Muslimmajority countries is within his powers as President. He is most able to accomplish things as a leader when he uses existing constitutional norms to achieve his policy aims. Yet even in these instances there is significant political pushback. The Muslim ban sparked mass global protest when it was first implemented because it was seen as patently xenophobic and discriminatory on religious grounds. Similarly the ending of DACA has led to cross-party proposals in Congress for passing some type of immigration reform to give legal immigration status to those undocumented immigrants who arrived in the US before they were 16 years old. The Dream Act has been stalled in Congress since 2010 despite major support from the Obama administration, ironically enough; Trump's actions may end up leading to some type of legal recognition for the 700,000 'Dreamers'. ${ }^{48}$ Even during the election campaign, when Donald Trump called for a 'total and complete shutdown of Muslims entering the United States' ${ }^{\prime 9}$ he was widely condemned

46 MD Shear and J Hirschfeld Davis, 'Trump Moves to End DACA and Calls on Congress to Act' New York Times (5 September 2017) Politics, <https://www.nytimes.com/2017/09/05/ us/politics/trump-daca-dreamers-immigration.html>.

47 E Shugerman, 'Trump Administration Has Ordered Deportations of 50,000 People since He Took Office' The Independent (8 August 2017) <http:/www.independent.co.uk/news/ world/americas/us-politics/trump-deported-50000-immigrants-department-of-justiceundocumented-immigration-a7883466.html>; Y Torbati and M Rosenberg, 'Trump Administration Proposes to Cut Refugee Cap to 45,000' (27 September 2017) <https://uk. reuters.com/article/uk-usa-immigration-refugees/trump-administration-proposes-to-cutrefugee-cap-to-45000-idUKKCN1C22SG>.

48 The term 'dreamer' refers to undocumented migrants who entered the United States as children. Deferred Action for Childhood Arrivals was a programme set up by the Obama Administration to offer the temporary right for these migrants to live, work, and study in the US. J Walters, 'What Is DACA and Who Are the Dreamers?' The Guardian (14 September 2017) US news, <http://www.theguardian.com/us-news/2017/sep/04/donald-trump-what-isdaca-dreamers>.

49 J Johnson, 'Trump Calls for "Total and Complete Shutdown of Muslims Entering the United States"' Washington Post (7 December 2015) Post Politics, <https://www.washingtonpost. $\mathrm{com} /$ news/post-politics/wp/2015/12/07/donald-trump-calls-for-total-and-complete-shutdownof-muslims-entering-the-united-states/>. 
for speaking in racist and incendiary tones. His attempts to racialise immigration discourse breached the norm that US immigration policy should be colour-blind - at least in theory, if not in practice. And that rhetoric, combined with regressive immigration polices has mobilised pro-immigration forces in both the US and globally to push for greater protections of mobility rights.

What we see in all of these instances is a pattern of Trump breaching a widely accepted norm, and a massive backlash to defend the norm when that breach occurs. Much of the coverage of the Trump administration from his first year in office has focused on how his actions might be destroying existing norms and in the process undoing liberal democracy. While we should not underestimate the threat that Trump poses to the global order, by treating Trump as a natural breaching experiment we can see that the controversies he causes actually point to widely shared understandings of what is acceptable and unacceptable behaviour. Through challenging global norms Trump is actually exposing the bedrock of the global constitution. This does not mean that Trump is no threat to constitutionalist norms. But it does mean that such a threat can be effectively countered to some extent by activists around the globe mobilising to protect these threatened norms, potentially leading to a deeper more selfconscious embrace of these norms. The activists in the \#MeToo, immigrants rights, and environmental movements in 2017 all demonstrated that by mobilising against Trump when he breaches a norm, not only is it possible to resist Trump implementing a policy, but that such resistance may actually lead to more widespread acceptance and implementation of the very norm that Trump sought to undermine. In a sense, Trump's pattern of norm breaching also points a path towards a dialectic of norm contestation. While there is no guarantee that this pattern will continue, or of the outcome of any particular instance of norm contestation, the fact that Trumpism has mobilised such a strong defence of norms of democracy, human rights, and the rule of law is a highly significant development. In Twilight of the Idols, the German philosopher Friedrich Nietzsche famously wrote ' $[t]$ hat which does not kill us makes us stronger'. ${ }^{50}$ The constitutional dialectic that Donald Trump's actions have sparked provides an opportunity to discover - and to strengthen - the resilience of national and global constitutionalism.

50 F Nietzsche, Twilight of the Idols or How to Philosophize with a Hammer, trans D Large (Oxford University Press, Oxford, 1998) section 8. 